\title{
Appraisal of African Identity for Sustainable Development
}

\author{
Michael Chugozie Anyaehie \\ Department of Philosophy, University of Nigeria, Nsukka, Nigeria \\ Email: mikeanyaehie@yahoo.com
}

Received November $9^{\text {th }}$, 2012; revised December $10^{\text {th }}$, 2012; accepted December $25^{\text {th }}$, 2012

\begin{abstract}
Africa is the poorest continent in the world despite her huge human and material resources. She is at the periphery of global development. Some people attribute the African predicament to her experience of slavery and colonialism which distorted her identity and disoriented her values. But she is not the only continent that was colonised. Other colonised continents are already finding their bearing in global development. What is that unique factor about African identity that hinders her from having her own stake in global development? This paper argues that Africa's stable and rich natural environment which does not coerce her to struggle for survival makes Africa docile and complacent. This psychological disposition makes her to take her survival for granted and to live on the providence of her environment without conscientious effort to conquer and drive it to enhance her state of life. The search for African identity should not focus on just exhuming her past culture and lamenting her experiences, but on discovering the latent prowess of Africa that will help her to positively and effectively confront her existential challenges. Colonialism and neo-colonialism are parts of Africa's existential challenges which she has to tackle to define her identity. For sustainable development, Africa has to wake up from her slumber of eulogising her cultural heritage and blaming others for her predicament, and brace up to critically, constructively and pragmatically evaluate her past, confront her current challenges and take responsibility for the effect of her actions and inactions.
\end{abstract}

Keywords: African Identity; Sustainable Development; Colonialism; Complacency; Responsibility; Authentic Existence

\section{Introduction}

Since the middle of 20th century, African scholars have been battling with rediscovery of African identity after the devastating effect of European slavery and colonisation. Most of the scholars argue that European slavery and colonialism devastated African psyche, rubbished her culture and values, and left her empty of any coherent world view of reality. The travails and backwardness of Africa in social, economical, and political development have been blamed on European colonialism and neo-colonialism. Fifty years after most African nations have become politically independent; many African scholars still blame the Western world for the backwardness of the continent. The situation is worrisome when we consider that other continents that were colonised like Africa are picking their pieces and advancing their development.

The question that agitates the mind here is, why is it that Africa cannot rise above her experience of European invasion and actualise herself? Man is always confronted with challenges and what distinguishes a people is how they are able to manage and overcome their challenges. It is the opinion of this paper that part of the problems of African underdevelopment is the Africa psychological complacency necessitated by abundant resources and environmental friendliness that sustains life at minimal stress. The search for African identity should not just focus on the past culture and achievements of the continent but also on the contemporary prowess of the continent that can propel her to overcome this psychological complacency and work towards greater heights in achievements that will attract the attention of the world. It is of age that Africans should stop lamenting the evils of European invasion and continual manipulation of the continent and confront the challenges the contemporary world order has in stock for her. The continent cannot develop on the terms of sympathy from other continents but on the strength of authentic and realistic confrontation of her challenges with the intention of overcoming them by herself and defining her existence in the world affairs.

\section{Colonialism and Loss of African Identity}

The Europeans propelled by spirit of modernism aimed at conquest of the world to enhanced their living and aided by sophisticated culture and technology; embarked on empire expansion and subordination of other regions of the world. The progressive industrialised European culture was contrasted with traditional societies of the parts of the world they conquered and colonised, such as America, Africa, Australia and Asia. "Other cultures were identified as having reached a stage through which Europe itself had already passed-primitive hunter-gatherer; farming; early civilisation; feudalism; and modern liberal-capitalism. Only Europe was considered to have achieved the last stage.” Many European writers of this time construed the history of Europe as paradigmatic for the rest of the world (Eurocentrism (2012) Wikipedia, The free encyclopedia). The perception of European as having superior cultural and technological sophistication led to widespread assumptions of her superior personal, intellectual and moral value. Such racist orientation was used to justify slavery, genocide and other forms of political and economic exploitation.

This was the global socio-political stage when Europe in- 
vaded Africa. On the conquest of Africa, the European colonisers embarked on the domination and suppression of African culture. There were no efforts to dialogue with African Culture. It was simply discarded as backward, primitive and lack any positive value to warrant any serious consideration. African cultures were disparaged as barbaric, primitive, irrational and debased. Her gods were declared evil and African race was classified as inferior to Europe. European colonialism enthroned eurocentrism in Africa which considers any culture that does not conform to it as inferior and need to be transformed to meet European standard. It disrupted and destabilised African values, beliefs and perception which define the people. Africa lost her identity. Many scholars have traced the problem of Africa's underdevelopment to the issue of identity crisis. Africa is the poorest continent in the world despite her numerous human and material resources.

With Eurocentric mentality, the colonisers embarked on reorientation of Africa to perceive the world from the European angle; a programme they called civilisation of African brutes. Hence the French embarked on assimilation of African elites into French culture. Fredrick Engels advanced that Africa should submit to European imperialism and transformation of her culture if she is to be civilised and avoid being extinct. G. W. F. Hegel (1956) declares that Africa has no contribution to human history and that she at best hears only echoes of human civilisation. Religious groups especially Christians and Moslems also embarked on re-orienting African worldview and consciousness. The European mission disoriented African psyche, perception, values and beliefs. Kwame Nkrumah (1974) holds that African identity has been distorted by Arab Islam, European Christianity and colonisation. Maduabuchi Dukor (2010) following the same line states that African identity is lost because of three major factors of European imperialist activities in Africa which includes slavery, colonialism and racialism. He states that,

It was because Africans were considered racially inferior and culturally uncivilised that both Arabs and Europeans felt a moral justification in exploiting them by reducing them to slavery. Therefore the heart of the whole problem of African identity lies in Racialism (Dukor, 2010: p. 159).

\section{Quest for Rediscovery of African Identity}

Since the middle of 20th century African nationalists and scholars have been trying to remedy the atrocities of European colonisation and slavery. Like Dukor, many African scholars lay the blame of Africa's stunted development and all the woes of Africa underdevelopment on the devastating effect of European slavery and colonisation of African, and engage on the mission of liberating Africa from the clutches of eurocentrism. They try to rediscover the authentic African self believing that it is pivotal for African liberation from the impact of colonial and neo-colonial exploits of the West.

Leopold Senghor (1963) trying to rediscover African identity canvassed for negritude in which there should be revival and promotion of traditional African culture and values. He advocated that Africa should be proud and embrace her culture; and she should not feel inferior to any other race. He argues that every race is psychologically, metaphysically and epistemologically unique. Each race has its peculiar way of perceiving, knowing and relating to reality and these are what determine the uniqueness of people's civilisation. Senghor argues that the whole complex of African values is greatly dependent on the mode of African cognition of reality and his psychology. The African mode of cognition he says is intuitive reason; all the values characteristic of Negro-African civilisation is essentially informed by intuitive reason. By intuitive reason he means that the Negro African is emotive in his cognition and relation with reality. He affectively participates in the object of his experience. The emotions of empathy with nature, rhythm and gift of myth-making are elements of African consciousness which manifest in his social and cultural activities. Senghor maintains that the distinctive quality of the European mind is reason. The European is dispassionate with nature. He rationally encounters the elements of his experience subjecting them to logic and analysis. He therefore, declares that reason is European, emotion is African. He then advocates that Africa's emancipation from European imperialism and neo-colonialism should be pursued from appreciating African intuitive reasoning and revival of African culture and attitude to reality with the aim of universalising and making them relevant to modern reality. African civilisation must reach out to the meeting point of all human civilisations and present the gains of African civilisation to the entire humanity.

Senghor's racialising the cognitive process of people has been criticised by scholars as presenting the Africans to be cognitively different from the Europeans. It tends to suggest that the Africans lack the ability of rational analysis necessary for modern science and technology and that Africans should evolve a distinct African science to showcase to the world. Intuitive reasoning cannot be said to be peculiar to Africa but it is an attribute of people at certain level of development irrespective of their race. His racial distinction of cognition to present Africa as unique and not inferior to Europe to boast the ego of Africa cannot help her to overcome her underdevelopment and marginalised status in the world.

Many scholars and nationalist pursuing culture revival try to come up with certain solutions to African problems. Julius Nyerere (1968) in his Ujamaa socialism tried to transform traditional Africa communalism based on family values into modern economic system and state administration. His trial of Ujamaa socialism in Kenya failed. The failure of the programme is to a great extent because of its inability to address the current existential reality of the time. The socioeconomic situation of the time where the people has imbibed capitalist ideologies and the global economic forces crumbled the programme.

Paulin Hountondji (1983) arguing for Africa overcoming her predicament states that Africa should not be sentimental about their culture in appraising their relevance to the contemporary challenges. Traditional culture and collective thoughts of Africans should be submitted to a critical assessment and not being unnecessarily apologetic. Those cultural traits that stand the test of critical scrutiny should be appropriated and advanced while those that fail should be modified or jettisoned. Hountonji tried to overcome the anachronistic orientation of negritude. Africa should come to terms with the current realities and not try to isolate herself or over lament about her past. Africa should address the current picture of things for her to be relevant in the global socio-politics and effectively handle her challenges. Propagandist approach of negritude which is popular with many African scholars confuses and complicates the problems of Africa.

Kwame Nkrumah (1970) in his Consciencism teaches that 
African mind has been adulterated with influences from Islam, Christianity and colonialism. It will be almost impossible to decipher traditional African culture from the foreign ones. What should concern Africa now is to understand her current plight and to address issues from that perspective. She can borrow ideas from other cultures of the world and adapt them to serve her interest. Nkrumah emphasises that there are nothing particular about the races; what matters is interest.

We need to appreciate with Nkrumah that African culture like every other culture is dynamic. The psyche and worldview of contemporary Africa have changed from that of her forefathers. When people agitate for the revival of traditional African culture the question that comes to mind is whether it is that of ancient Africa that addressed the challenges of that age. Many of the solutions of that age are no longer relevant to current problems of Africa. The search for African identity should focus on how to understand the present mind set of Africans, highlighting his potentials and limitations in tackling current existential global problems. A look at Africa's past history may be informative to her current perception of reality, but the search should go beyond that to analyse her present challenges and attitude to things.

\section{Actualising African Identity for Sustainable Development}

It is important to highlight here that we need not over emphasis the evils of European invasion and colonialism as the major causes of Africa's underdevelopment. The plight of any people is interplay of both objective and subjective factors, and external and internal factors. The West may not be paternalistic, but self centred in their dealings with Africa and other parts of the world. But who is paternalistic in the face of global competition. What drive global affairs are national interests. Africa should jettison the idea that any people will spend their resources to salvage her if it does not serve their interest. Africans are the only people who can salvage Africa. No people can be great on the shoulders of others. The business of the search for African identity should be to discover the current worldview (metaphysics), psychology and aspiration of Africa that could be harnessed to elicit authentic, innovative and productive orientation. Africa should wake up from her slumber and creatively confront the challenges of her time.

Africans are intellectually able like any other race. This has been manifested in the achievement of Africans in diasporas. It is disturbing that the heights which Africans achieve in other lands are not replicated in Africa. The problem is environmental. Africa is the most stable continent in the world. It has stable climate round the year that sustains life with minimal effort. Other continents yearly battle with extreme weather conditions like winter that requires serious effort to survive. She is not challenged with natural disasters like hurricanes, tsunamis and earthquakes. She is blessed with abundant resources that can sustain life with minimal effort. She is not compelled to develop long term plans to survive. Each day provides for itself. That is why when there is any disruption in the other of things it brings untold hardship to the people. The implication of this is that Africa is not consistently coerced by nature to struggle for survival. The richness and stability of Africa's natural environment made him to be complacent and not aggressive about life. He takes survival for granted.

The African environment does not demand one to be critical of his actions for him to survival. The complacency with which he confronts life makes him to believe anything and be contented with the minimum. He is contented with things around him and has no zeal to question and disrupt the peaceful status quo. J. M. Nyasani argues that community norms,

Are merely received but never subjected to the scrutiny of reason to establish their viability and practicability in the society ... May be, it is lack of personal involvement and personal scrutiny that has tended to work to the disadvantage of the Africans especially where they are faced with a critical situation of reckoning about their own destiny and even dignity (Nyasani, 1997: pp. 63,69).

The sense of security provided by the environment also impacted on African social system. African communalism promotes such social values like liberalism, accommodation, hospitality and docility in human relation which also provides socioeconomic security for survival of all irrespective of individual productivity. Within the communal context, J. M. Nyasani states that Africans exhibit an

Endemic and congenital trait of what could be described as a natural benign docility generally brought about by years of blind social submission and unquestioning compliance to the mystique of higher authority that reigns surreptitiously yet effectively in all black African societies in varying degrees. This benign natural docility is generally regarded as positive, legitimate and virtuous strictly within the context of a traditional social regime (Nyasani, 1997: p. 113).

Kwasi Wiredu discussed three maladies of African culture that are inimical to development: anachronism, supernaturalism and authoritarianism. These maladies are consistent with this African docility.

African society is essentially traditional. A society is traditional if its members' behaviour continues with minimal change of pattern from generation to generation. Such society is always custom-bound, hierarchical, ascriptive, uncritical and not innovative. Messay Kebede argues that the failure of development of Africa is due to her persistent attachment to tradition be it that of Africa or that of her colonial master and not being innovative. This accounts for her orientation of blindly copying institutions and cultures without critical examination and adaptation to suit her existential condition. According to him Africa's underdevelopment can be traced to her,

internalisation of the colonialist discourse, which in itself has become a new tradition imposed on older traditions. For no resurgence of innovative capacity can take place so long as internalization of the colonialist argument paralyses the African mind. Mental decolonization thus emerges as top priority in Africa's development agenda (Messay

Kebede, 2004: p. 108).

Africa is not the only continent that was colonised. The other colonised continents are consistently making improvements and impacting on the world development. Asia, South America and Australia are colonised continents that are strongly emerging in global affairs. Their driving force is that they are confronting their challenges as it suits them not as the world want them to do. Asia aggressively minimised foreign influences on her affairs to constructively position herself for effective develop- 
ment. Conversely, Africa always solicits for foreign interferences in handling of her challenges.

Human knowledge and development evolve through contribution of insights of people of different epochs as they try to resolve the challenges of their existence. Each people at every epoch of their life have existential challenges and how they manage the challenges define their being. That is why John Paul Sartre (1977) asserts that man is an indeterminate being. He defines himself as he acts through life. Situations do not determine man, but they constitute pillars with which man defines himself. Authentic life is man's ability to use the challenges of his situation to actualise his aspiration. Inauthentic life is when one allows his situation to overwhelm and define him.

Human needs necessitate human interaction. As human needs continue to expand, interactions continue to expand to reach people at the extremes of the world. This brings about culture contact and interactions. Africa cannot exist in isolation of other peoples. It is pertinent to observe here that culture is the totality of a people's innovativeness in the sustenance of their existence. Culture could be physical, intellectual or behavioural. The meeting of cultures brings about appraisal and crystallisation of the cultures to bring about a superior culture that will accommodate, on the principle of efficiency, the positive traits of the different cultures and discard the negative or less efficient traits. In this act of synthesis of cultures, they influence and sharpen each other to realise the most efficient system that will address contemporary issues. This brings in the issue of globalisation and the need for Africa to proactively appraise her culture in the light of the current global trend of things.

It is true that Africa came in contact with Western culture as underdog considering the sophistication of Western culture at the time; and the colonizers attitude of domination and suppression of African culture, but the ease with which Africa uncritically abandon her culture for Western culture reflect the African docility and complacency. The search for African identity should ginger African intellectual and cultural renaissance in which African metaphysics, epistemology and psychology should be critically overhauled to bring out the best of curiosity, creativity, innovativity and productivity from Africa. Both African culture and that of other continents should be brought to the table of critical appraisal with the aim of evolving mental attitude, values and practices that will pragmatically address African predicament. This will involve sieving the best of global cultures as they suit Africa, and creatively and innovatively blending them for effectiveness.

For purpose of comparing cultures, let us briefly look at the emergence of Western modernism which has propelled her to the pride of place in the world. After centuries of suppression of curiosity and innovative intellectual creativity by dogmatism of Christendom, the 15th and 16th centuries' enlightenment and renaissance of Europe ushered in rapid intellectual development aimed at liberating the people's mind and making them to re-evaluate the efficiency of their traditional beliefs in handling their challenges. The radical approach to their human existence gave rise to the 17th and 18th centuries' industrial revolution which transformed Europe and gave it a pride of place in the world history. It transformed the social, political and economic life of Europe towards maximisation of efficiency of action. The renaissance brought the world down from its high sacred place and subjected it to human critical rational scrutiny aimed at improving human life. Modern Western philosophers like
Hobbes advanced mechanistic conception of the world anchored on humanism. Under Berkeley, the mind becomes measure of all things - to exist is to be perceived. Bentham and the Mills settled for utilitarian principle for determination of morality of human action. While Hegel anchored human history on rationality, Karl Marx reduces it to economic forces. Jean Paul Sartre leaves the world to what you make out of it. With this kind of philosophy, the West embarks on the quest to conquer the world and make the most economic profit of the conquest. This is what propels the spirit of modernism. Modernism is the aspiration for innovative creativity unencumbered by traditions to achieve results in human development.

\section{Conclusion}

Africa should emulate the spirit of modernism to transform her predicament. Emulating the spirit of modernism is not the same as copying Western culture. It is being critical and subjugating every issue to rational examination with the aim of mastering and controlling it for ones interest. Africa should absolve herself from the life of docility, passivity and dependence on fate and try to rationally and creatively confront her existence with the aim to be in charge. Poverty, political instability, corruption and other social malaise in Africa are due to the fact that she is too tolerant and permissive of evils around her with the hope that God and nature will address the evils. This brings about excessive religiosity, over dependence on the good will of people, attachment to tradition and resistance to innovations and changes. All these encumber free rational creativity and innovativeness necessary for transforming the psyche and actions of people that will bring about positive changes in socioeconomic life of Africa. The political office holders are corrupt and the nations are in the state of decay because the people are not ready to struggle to bring sanity. They look up to God and foreign nations to come and wage their fight. When the foreign nations come they do it their own way to satisfy their interest which most often is inimical to African interest. Africa should take her destiny into her hand and be ready to take full responsibility of her predicament. No gods or people can be blame for African backwardness rather African plight is the result of her actions and inactions. It is only when Africa internalises this truth that she can be on the part of her renaissance and sustainable development.

\section{REFERENCES}

Dukor, M. (2010). African freedom: The freedom of philosophy. Germany: Lap Lambert Academic Publishing GmbH \& Co. KG.

Eurocentrism (2012). Wikipedia, The free encyclopedia. URL (last checked November 2012). http://en.wikipedia.org/wiki/Eurocentrism Hegel, G. W. F. (1956). The philosophy of history. New York: Dover Publications.

Hountondji, P. (1983). African philosophy: Myth and reality. Bloomington: Indiana University Press.

Kebede, M. (2004). African development and the primacy of mental decolonization. African Development, 29, 107-129.

Nkrumah, K. (1970). Consciencism: Philosophy and ideology for decolonization. Michigan: Monthly Review Press.

Nkrumah, K. (1974). Neo colonialism: The last stage of imperialism. London: Panef Book Ltd.

Nyasani, J. M. (1997). The African psyche. Nairobi: University of Nairobi and theological Printing Press Ltd.

Nyerere, J. K. (1968). Ujamaa: Essays on socialism. London: Oxford University Press. 


\section{C. ANYAEHIE}

Sartre, J. P. (1977). Existentialism and humanism. London: Eyre Mephuen.

Senghor, L. S. (1970). Negritude: A humanism of the twentieth century.
In W. Cartey, \& M. Kilson (Eds.), The African reader. New York: Vintage Books. 